\title{
Can Homeopathic Arsenic Remedy Combat Arsenic Poisoning in Humans Exposed to Groundwater Arsenic Contamination?: A Preliminary Report on First Human Trial
}

\author{
Anisur Rahman Khuda-Bukhsh ${ }^{1}$, Surajit Pathak ${ }^{1}$, Bibhas Guha ${ }^{1}$, Susanta Roy Karmakar ${ }^{1}$, \\ Jayanta Kumar Das ${ }^{1}$, Pathikrit Banerjee ${ }^{1}$, Surjyo Jyoti Biswas ${ }^{1}$, Partha Mukherjee ${ }^{2}$, \\ Nandini Bhattacharjee ${ }^{1}$, Sandipan Chaki Choudhury ${ }^{1}$, Antara Banerjee ${ }^{1}$, Suman Bhadra ${ }^{1}$, \\ Palash Mallick $^{1}$, Jayati Chakrabarti ${ }^{1}$ and Biswapati Mandal ${ }^{2}$
}

${ }^{1}$ Department of Zoology, University of Kalyani and ${ }^{2}$ Directorate of Research, Bidhan Chandra Krishi Viswavidyalaya, Kalyani-741235, West Bengal, India

\begin{abstract}
Groundwater arsenic (As) has affected millions of people globally distributed over 20 countries. In parts of West Bengal (India) and Bangladesh alone, over 100 million people are at risk, but supply of As-free water is grossly inadequate. Attempts to remove As by using orthodox medicines have mostly been unsuccessful. A potentized homeopathic remedy, Arsenicum Album-30, was administered to a group of As affected people and thereafter the As contents in their urine and blood were periodically determined. The activities of various toxicity marker enzymes and compounds in the blood, namely aspartate amino transferase, alanine amino transferase, acid phosphatase, alkaline phosphatase, lipid peroxidation and reduced glutathione, were also periodically monitored up to 3 months. The results are highly encouraging and suggest that the drug can alleviate As poisoning in humans.
\end{abstract}

Keywords: arsenic toxicity - Arsenicum Album-30 - enzyme biomarkers - homeopathy human trial - remedy

\section{Introduction}

Prolonged exposure to arsenic (As), a toxic metalloid, has caused various illnesses to millions of people globally distributed over 20 countries. In Bangladesh and its adjoining part of West Bengal (India) alone, $\sim 100$ million people are at risk (1) of As poisoning because of drinking contaminated groundwater having concentrations of As ranging $60-560.23 \mu \mathrm{g} \mathrm{l}^{-1}$, much exceeding the maximum permissible limits laid down by both WHO (2) and US Environmental Protection Agency (3). The attempts made so far by both Governmental and Non-Governmental organizations to provide As-free drinking water to the highly affected areas remain grossly inadequate.

For reprints and all correspondence: Anisur Rahman Khuda-Bukhsh, Department of Zoology, University of Kalyani, Kalyani 741235,

West Bengal, India. Tel: +91 $3325828768(\mathrm{R}) ;$ +91 3325828750 ext. 315(O); Fax: +91 33 25828282; E-mail: khudabukhsh_48@rediffmail.com, prof_arkb@yahoo.co.in
Furthermore, As enters the bodies of unsuspecting villagers not only through drinking water alone but also a substantial amount enters through food and vegetables grown in contaminated land around the village (1). We, therefore, feel that serious efforts should also be directed to remove As after it enters the body. However, orthodox medicines (e.g. chelating agents like Dimercaptosuccinic acid (DMSA), Diethylenetriamine-pentaacetic acid (DTPA) etc., and some antioxidants) have been most unsuccessful $(1,4,5)$. Chronic exposure generally leads to various ailments and the dysfunction of several vital organs like the liver, kidney, lung, etc. (6), more often when there is an accompanying nutritional/dietary deficiency (7). Most of the affected people in general complain of muscle and joint pains and are highly depressed with various gastric problems and general weakness. Many people look pale and anemic and seem resigned to fate. In such a scenario, our efforts are directed to find a remedy that is inexpensive, easy to administer, effective in low doses and has no toxic effect

(C) The Author (2005). Published by Oxford University Press. All rights reserved.

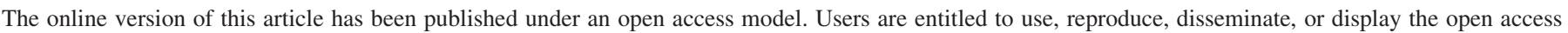

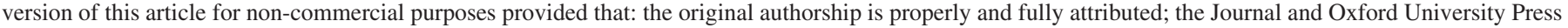

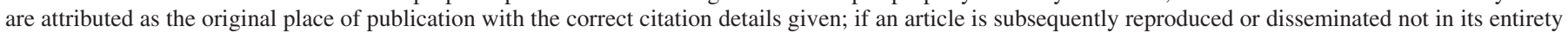
but only in part or as a derivative work this must be clearly indicated. For commercial re-use, please contact journals.permissions@oxfordjournals.org 
of its own. The encouraging results of early attempts $(8,9)$ to mobilize Arsenic in rats through microdoses of Arsenicum Album, and our extensive studies in mice (10-16) suggested that Arsenicum Album-30 has the potential to alleviate As toxicity in humans as well. The favorable response to an early trial $(17,18)$ prompted us to undertake this first human trial, the initial results of which are reported in this paper.

In this trial, we monitored the changes in As concentrations in urine and blood and also the activities of several enzymes and toxicity biomarkers, viz., aspartate amino transferase (AST), alanine amino transferase (ALT), acid phosphatase (AcP), alkaline phosphatase (AlkP), lipid peroxidation (LPO) and reduced glutathione (GSH) after administration of the ultralow doses of the Arsenicum Album-30. Any increase in the concentration of As in the urine accompanied/ followed by a decrease in the blood after drug treatment was viewed as resulting from the removal of As from the body. Similarly, any increased activity in the favorable biomarkers and decrease in enzymes indicating toxicity were taken as evidence of alleviation of As toxicity.

\section{Methods}

\section{Subjects}

Arsenic Location: As was first detected in 1995 in the tube wells of the village, Ghetugachhi under Chakdaha Block, District Nadia, West Bengal. As-free water plant was subsequently installed in November 2002 in this village, after a huge mortality had been reported due to arsenicosis. From that time, villagers were warned against drinking water from any other source (few tube wells in the village were sealed by the Government) and advised strictly to use water of the As-free plant for drinking purposes. However, most of them use other water sources for cooking and other purposes and occasionally drink contaminated tube well water when they work in the field. Therefore, even though these villagers are at risk of As contamination to a lesser degree than before and have a lower mortality rate, many people still show symptoms of arsenicosis albeit to a lesser extent.

Group One: When the villagers were initially approached with the request to act as volunteers in our trial on the efficacy of a potentized homeopathic drug, Arsenicum Album, most of them were visibly reluctant, presumably because (i) many of them simply did not believe in homeopathy; and (ii) some researchers had earlier taken blood, urine, nail and hair samples promising to give effective remedies, but never came back with the results or the promised remedy! After great persistence, however, a group of 55 people comprising 32 males and 23 females (Group I, Table 1) living in this village agreed to become subjects of a double-blind placebocontrolled trial only for analyzing urine As content for a few days (11 days only). The persons of this group took a dose of either 'verum' (Arsenicum Album-30 soaked globules) or 'placebo' (Alcohol-30 soaked globules) twice daily for 10 consecutive days, each dose containing eight small globules
(No. 20) soaked with the medicine/placebo. The information whether they were taking the placebo or the drug was kept from them. At the end of the experiment when the codes were deciphered it was found that 22 and 33 persons received 'placebo' and 'verum', on a random basis. The urine samples were taken daily up to 11 days after the first administration of drug/placebo and analyzed for As content. These data were critically analyzed and were utilized as controls for another group of people (Group II), who were persuaded later to undertake the trial for a longer period and were requested to give not only urine samples periodically, but also blood as well, so that not only the relationship of As concentration in urine and blood could be fairly extrapolated but also some other toxicity biomarkers could be studied from their sera.

Group Two: Although a group of 68 randomly selected persons comprising 47 males and 21 females (Group II) from the same village agreed to donate urine and blood samples, they refused to sign 'informed consent' unless they were assured that they would receive the actual drug and not any 'placebo'. This was understandable, since many of them were indeed very sick, suffering from serious liver and lung ailments, and bad skin lesions in the case of a few. Our earlier results on randomized placebo-controlled animal experiments clearly showed that the potentized homeopathic remedy Arsenicum Album-30 ameliorated As toxicity as revealed from various protocols (10-16). On humanitarian and ethical grounds of trying to alleviate their suffering (there are no hospitals or medical clinics nearby this village to render any emergency service to the subjects, if necessary), we agreed to give these subjects (Group II) only 'verum', twice daily for 10 consecutive days, each dose containing eight small globules (No. 20) soaked with the medicine and then the remedy was withdrawn for 15 days. Thereafter, the cycle was repeated twice in the same manner. Subsequently, the drug was administered only for seven consecutive days, keeping always a gap of 15 days in between.

The volunteers of both Groups I and II were advised to take As-free water (from a plant nearby, water from which measured $<10 \mathrm{ppb}$ of As at periodical surveys) to the maximum possible extent during the course of the experiment, although they had actually been drinking water mostly from this plant ever since its installation. This was necessary because these people occasionally drink water from shallow tube wells contaminated with As after they exhausted the As-free drinking water they carried with them to the fields.

\section{Choice of Technique for As Determination}

In our initial trials for standardization of As determination in water, urine and blood, we used (i) acid undigested samples; (ii) partially digested samples by treating with a single acid solution; and (iii) fully digested samples with three acids (see below), taken in containers for digestion like (i) glass beakers followed by transfer to volumetric flasks before recording data in AAS; and (ii) directly in volumetric flasks 
Table 1. List of volunteers, their age, sex and brief health data

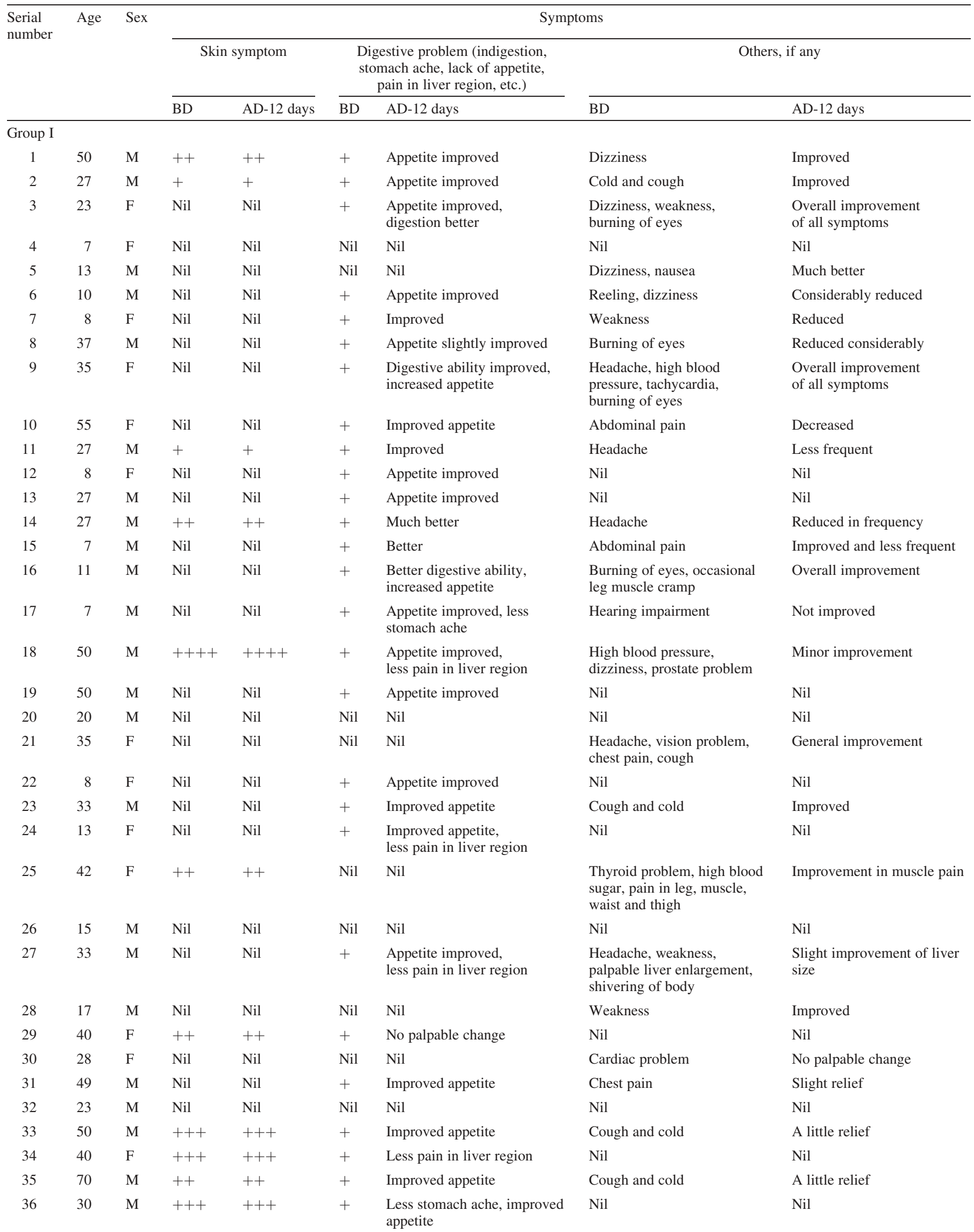


Table 1. Continued

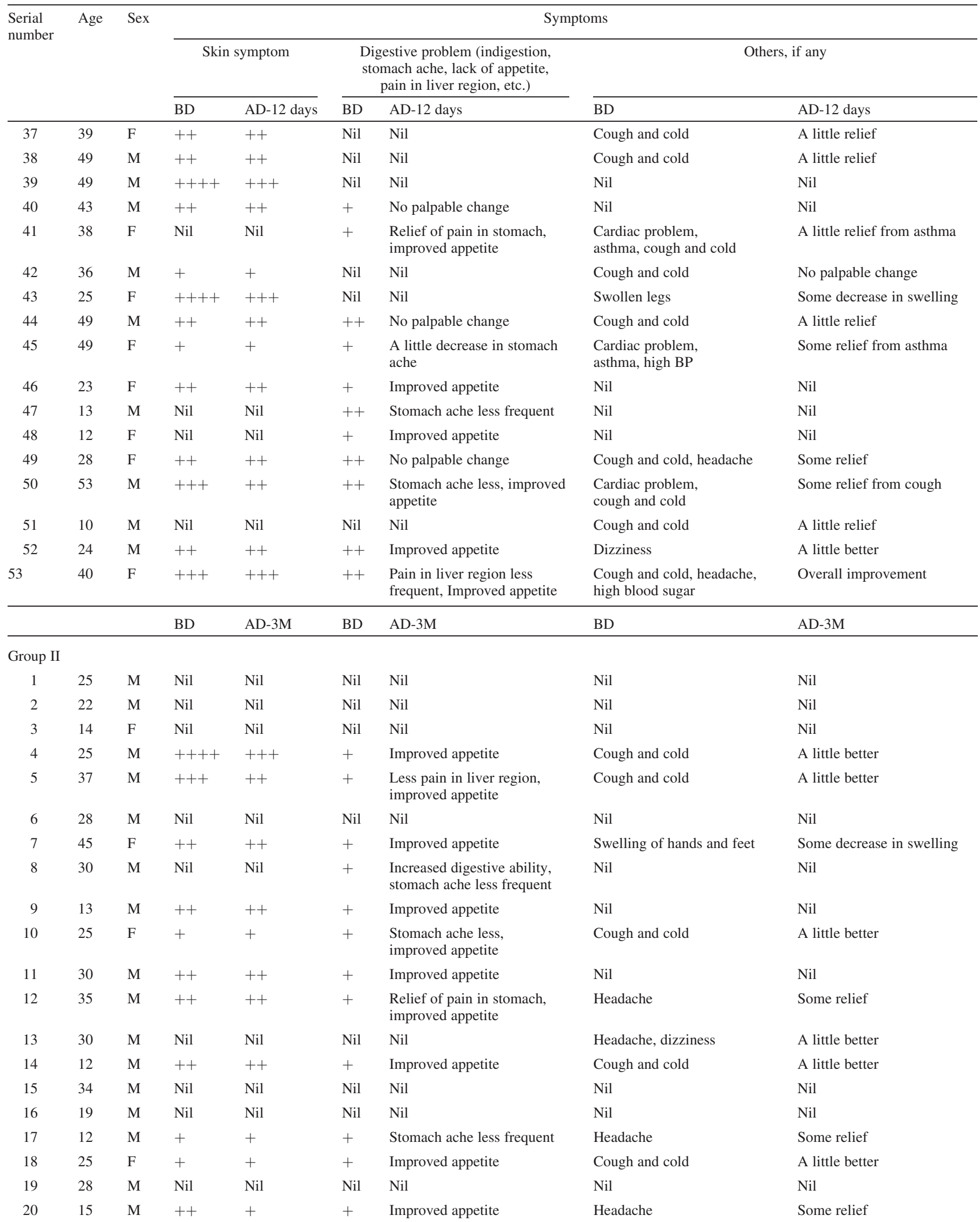


Table 1. Continued

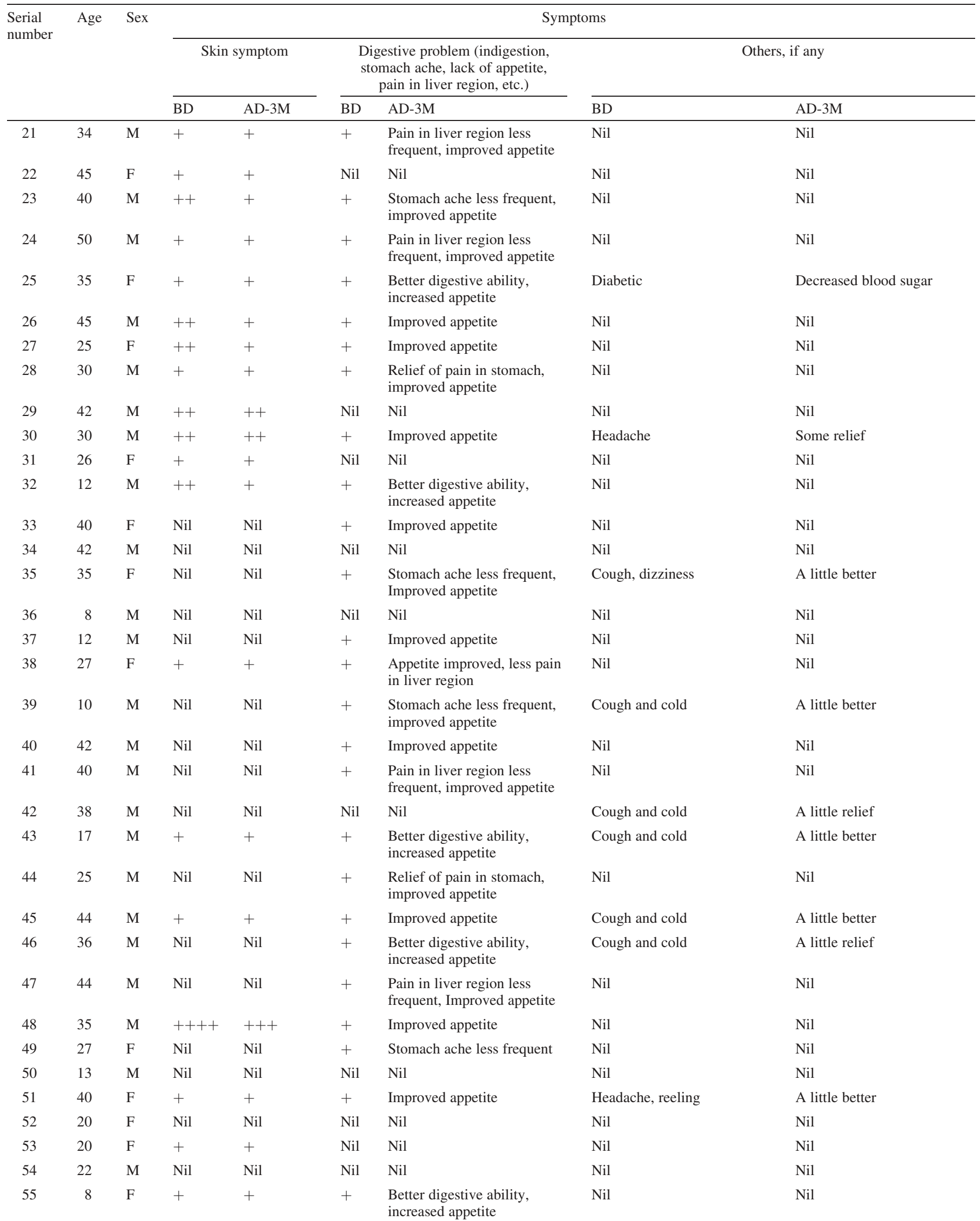


Table 1. Continued

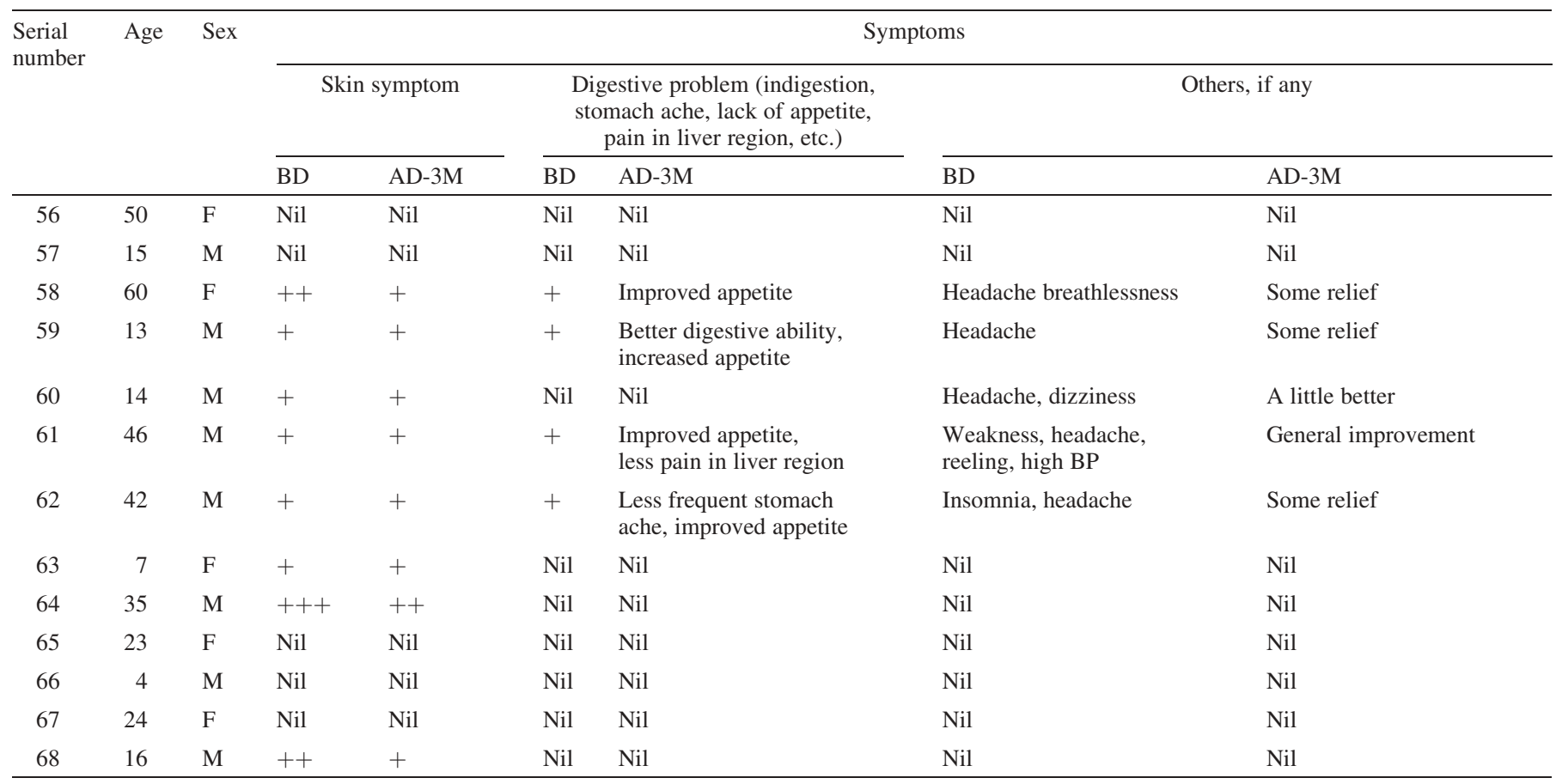

$\mathrm{BD}$, before drug; $\mathrm{AD}$, after drug; $\mathrm{M}$, month.

One ' + ' sign denotes one arbitrary unit of expression of disease state.

not necessitating transfer before running into AAS. Since we were more concerned with the inorganic (more toxic) than the organic As, we found the following method to be quite reliable producing consistent results. This was possibly due to less matrix effect, which tended to give erratic results at times with the other techniques.

\section{Analytical Methods for Estimation of As in Urine and Blood Samples}

\section{Sample Collection}

Water: Samples of drinking water from the As-free water plant and the 10 tube wells that were being used as a source of water for all domestic purposes, including cooking of food, were periodically brought to the laboratory to test their As content.

Urine and blood: First void urine samples were collected from all volunteers in separate sterilized preacid washed bottles. Blood samples were taken from the vein using a disposable hypodermic needle and transferred into two bloodcollecting vials - one containing EDTA for As analysis and the other without EDTA for serum analysis. Immediately after collection, the urine and a part of the blood samples were stored at $-20^{\circ} \mathrm{C}$ until further processing for As estimation in the laboratory.

\section{Preparation of the Samples for As Analysis}

Water samples were tested either by adding (i) only $\mathrm{HNO}_{3}$ (commonly done) or (ii) by adding a mixture of $\mathrm{HNO}_{3}$,
$\mathrm{HClO}_{4}$ and $\mathrm{H}_{2} \mathrm{SO}_{4}$ like that of urine and blood samples. Since there was negligible difference in As content shown by these two methods, we preferred to continue with the same method of triple acid treatment for all three samples.

One milliliter of each of the water, urine and blood samples was taken separately into $25 \mathrm{ml}$ volumetric flask, to which $5.0 \mathrm{ml}$ of a mixture of extra pure acids $\left(\mathrm{HNO}_{3} / \mathrm{HClO}_{4} / \mathrm{H}_{2} \mathrm{SO}_{4}\right.$ $3: 1: 1)$ was added and kept for predigestion for $\sim 2 \mathrm{~h}$. Subsequently, the flasks were heated to $170-180^{\circ} \mathrm{C}$ on a temperature-controlled hot sand bath. The digestion continued (for $\sim 5.0 \mathrm{~h}$ ) until a colorless liquid (of $\sim 1.0 \mathrm{ml}$ ) was obtained. After digestion, the flask with the content was cooled down overnight at room temperature. Further, to the content in the flask, $1.0 \mathrm{ml}$ of concentrated $\mathrm{HCl}$ (supra pure grade) and $1.0 \mathrm{ml}$ of potassium iodide $(\mathrm{KI})$ solution $\left(5.0 \mathrm{~g} \mathrm{l}^{-1}\right)$ were added with requisite amount of double distilled water to make the volume up to $25 \mathrm{ml}$ so as to get $\sim 200 \mathrm{mg} \mathrm{l}^{-1} \mathrm{KI}$ in the final solution to be aspirated in the hydride generator. The hydride (arsine) was generated by continuous mixing of the sample with a solution of sodium borohydride $(1.0 \%, w / v)$ and $\mathrm{HCl}(4.0 \mathrm{M})$. Arsenic content in the solution was determined with the help of a hydride generation atomic absorption spectrophotometer (AAS) at wavelength $193.7 \mathrm{~nm}$ and lamp current $8.0 \mathrm{~mA}$ [made up of GBC (Australia), model Avanta; equipped with a HG 3000 system]. All analyses were performed in triplicate including the blank. All chemicals used were of analytical grade. Standard As solution procured from E. Merck, Germany, was used as the standard for AAS calibration to detect As in all human samples. 


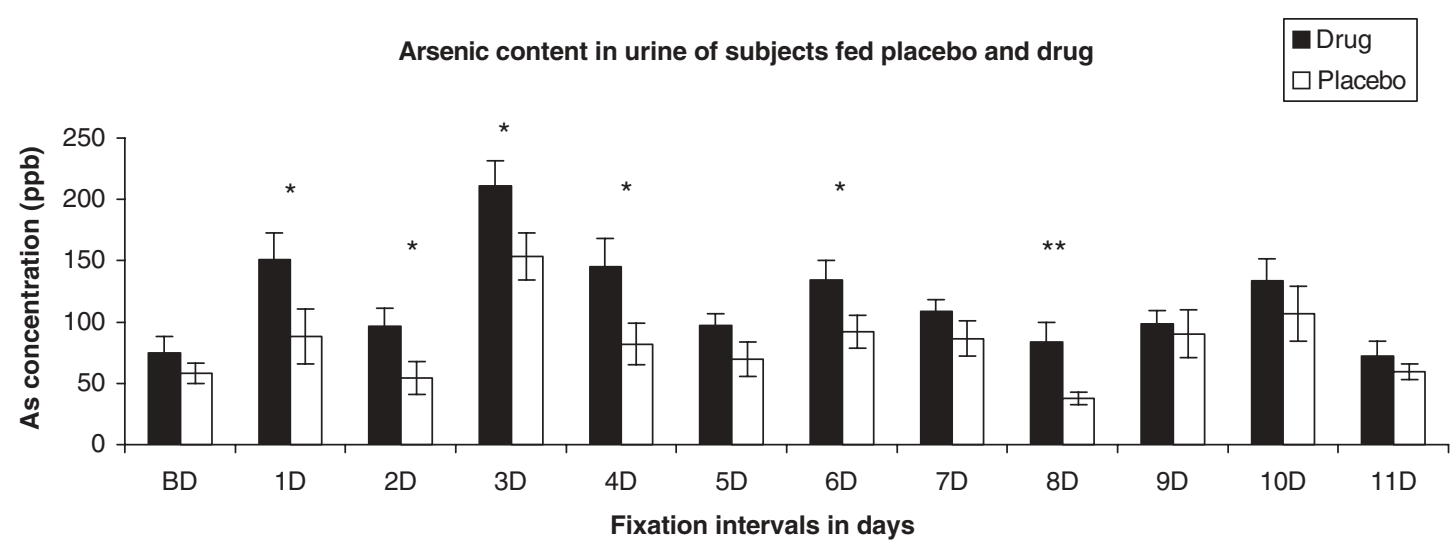

Figure 1. Arsenic (As) content in urine of verum fed subjects vs. placebo fed axes for 11 consecutive days. $* P<0.05, * * P<0.01$.

\section{Methods for Estimation of Enzymes and Other Biomarkers}

\section{Preparation of Blood Samples}

Blood samples were kept for $5-6 \mathrm{~h}$ at $37^{\circ} \mathrm{C}$ in the laboratory for isolation of serum. Serum was centrifuged at $10000 \mathrm{~g}$ for $30 \mathrm{~min}$ and $0.2 \mathrm{ml}$ of supernatant (serum) was taken and diluted with $19.8 \mathrm{ml}$ of phosphate-buffer saline.

All standard protocols for quantitative estimation of the enzymes were followed: e.g. Walter and Schutt (19) for AcP and AlkP, Bergmeyer and Brent (20) for AST and ALT, Buege and Aust (21) for LPO and Ellman (22) for GSH were followed.

\section{Dose of Medicine Orally Administered}

Eight small globules of pharmaceutical grade sugar (No. 20) soaked with Arsenicum Album-30 [Schwabbe German/Boiron Laboratories, Lyon, France, were prepared by following the homeopathic principle of dilution and succussion (see ref. (16) for detailed procedure of drug preparation)] to be taken twice daily half an hour before or after taking any food or beverage. Following homeopathic restrictions, patients were barred from taking raw onion or garlic during the period of the study.

\section{Statistical Analysis}

The SDs and errors were determined and the significance levels were calculated between the data of each parameter of study obtained before and after administration of the remedy for the specified periods of time by the Student's $t$-test.

\section{Results}

\section{Changes in As Content}

The mean As content of drinking water from the As-free plant was $<10 \mathrm{ppb}$, but the As contents of 10 tube wells providing water for other purposes varied from an average of 65.9-330.37 ppb from one tube well to the other.
Group One: Results of Group I (Fig. 1) showed that there was a fluctuation of As concentration in the urine of both 'placebo' and 'verum' fed subjects on a day-to-day basis but the concentration in the latter group was always higher compared with that in the former. The differences in the concentration between the two groups (drug versus placebo) were generally a little higher during the first week, but subsequently the differences were not so palpable, particularly at the 11th day. But from this study, it was quite evident that the efficacy of the 'verum' in the mobilization of As was always greater than that of the 'placebo' during all 11 days.

Group Two: The mean As content in urine and blood (Fig. 2a and $b$ ) of the patients (Group II) before administration of the drug was higher (being $43.75 \mathrm{ppb}$ in urine and $24.13 \mathrm{ppb}$ in blood) than the normal permissible range (3.33-25.55 ppb and $0.3-2.0 \mathrm{ppb}$, respectively) (23-28). The content in urine at 7 th day after administration of the drug was found to rise up to a strikingly high level (62.30 ppb), but thereafter it steadily declined to reach almost the lower limit of normal range by 45 th day (10.78 ppb) (Fig. 2a). Regarding the As content in the blood (Fig. 2B), a significant decline was recorded on the 30th day, returning to normal range on the 60th day after drug administration. Since the first estimation was taken only after 30 days, we do not know if it also increased like that in the urine at any point during the intervening period. A triggered release of As into urine on medication and its subsequent elimination from the body probably sets a new As equilibrium the blood that was eventually manifested later by a low As concentration in the blood.

\section{Changes in Toxicity Biomarkers}

Interestingly the activities of all toxicity denoting enzymes in blood, viz., AST, ALT, AcP and AlkP showed a steady decline and attained almost normal levels by 2 months time after drug administration (Fig. 3a-d). Concomitantly, the LPO activity also decreased with an increase in the GSH levels in the subjects (Fig. 3e and f). Extensive toxicological studies have now established that increase in LPO, AlkP and AcP activities along with a decrease in GSH levels denote cytotoxicity and hepatocellular dysfunctions associated with As toxicity 

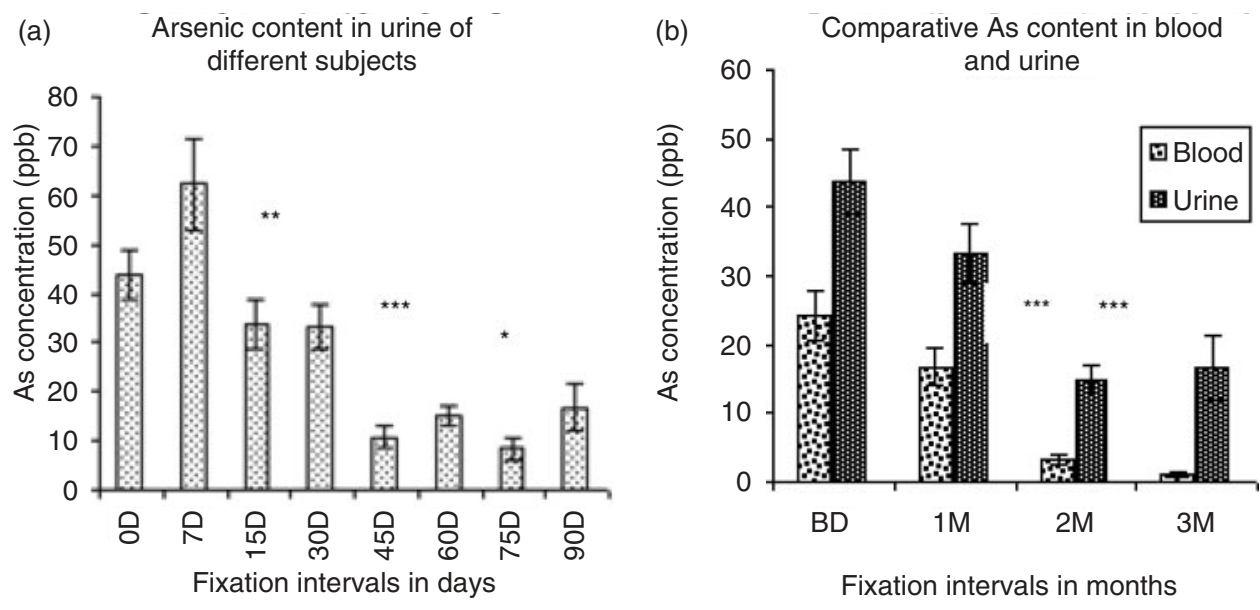

Figure 2. (a) Statistical significance test done between BD and 7D, and between successive fixation intervals, namely, between 7D and 15D, 15D and 30D, and so on; $* P<0.05$, $* * P<0.01$, $* * * P<0.001$. (b) Statistical significance test done between $\mathrm{BD}$ and $1 \mathrm{M}$, and between successive fixation intervals; $* P<0.05, * * P<0.01, * * * P<0.001$

(29-31). Our results also corroborated the existence of such correlations between As concentration in blood and urine and the activities of these enzymes (negative with GSH, and positive with AST, ALT, AcP, AlkP and LPO). A desirable change in these biomarkers (an increase in GSH and decreases in ALT, AST, AcP, AlkP and LPO) on drug administration suggests its potential in alleviating As toxicity in humans.

\section{Any Preference of the Remedy According to As Load or Sex?}

Pending a more critical analysis of the data on changes in As content in urine and blood and favorable changes in the activities of the enzymes, it was impossible to determine without further study if the drug was more effective in those with higher or medium loads of As in the body than those with lower levels. It was, however, clear that sex did not influence the efficacy. The drug was able to bring about statistically significant changes in the enzyme activities of both the urine and the blood As (Figs. 1, 2a and b).

\section{Improvements in other Aspects of Health}

Indeed, along with the changes in these parameters, the drug administration also improved considerably the overall physical strength, appetite and food digestion, and also mental cheerfulness in these subjects with a general feeling of better health. Even within 2 months, some volunteers with severe skin complaints started showing some amelioration of their symptoms (Fig. 4a-d).

\section{Discussion}

The results on various toxicity biomarkers obtained in the present study were apparently consistent with the reduction of As content observed in the different samples after the specified periods of drug administration. Our approach was holistic: by comparing the data of the pre-drug administration levels at different fixation times we sought to understand if the remedy was causing any positive modulations that indicated better health conditions in the subjects. This was done primarily to know if the administration of the remedy showed any positive modulations indicative of better health conditions of the subject.

Free radicals are electrophilic species that can react with cellular components. The process of LPO is initiated by the attack of a free radical, that could be emanated by As (32), on unsaturated lipids and the resulting chain reaction is terminated by the production of lipid breakdown products, lipid, alcohols, aldehydes and malonaldehyde. There is a cascade of peroxidative reaction in hepatotoxicity, which has been a common symptom of As victims. This ultimately leads to the destruction of lipid and thus the liberation and quantification of malonaldehyde reflects the state of hepatotoxicity. An increased level of LPO, therefore, may affect membrane structure by altering fluidity of the membrane. Interestingly, the enhanced activity of LPO observed in the baseline data has been considerably reduced following administration of the potentized homeopathic drug, which is a significant finding.

Phosphatases are enzymes that catalyze the splitting off of phosphoric acids from certain monophosphoric esters, a reaction of considerable importance in several body processes including neoplastic growth. AcPs and AlkPs have been directly implicated in the extent of cellular damage and toxicity (33-35), particularly of liver and cardiac tissue. The primary importance of measuring AlkPs is to check the possibility of mainly liver diseases (ALP-1) or bone diseases (ALP-2), which are prevalent in As victims. The level increases mainly as a result of liver, bile duct or gall bladder dysfunction, particularly in adults. The study of AlkP levels becomes significant in effectively denoting the alteration of toxicity levels during the period of drug administration. Similarly, the activities of enzymes like ALT/GPT (Glutamate pyruvate aminotransferase) and AST/GOT (Glutamate oxaloacetate 


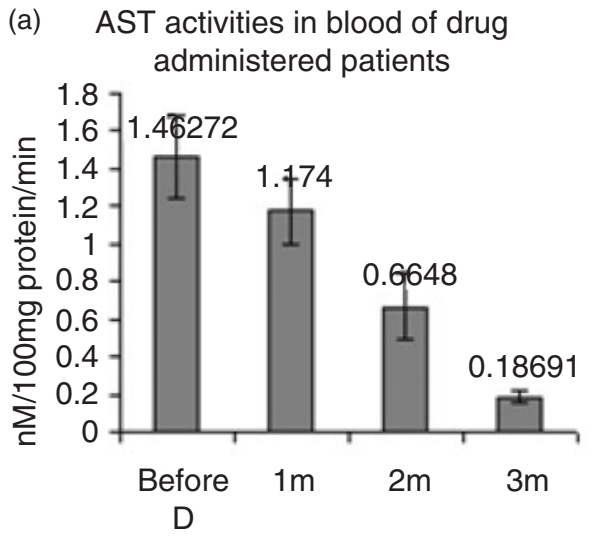

Fixation intervals in months
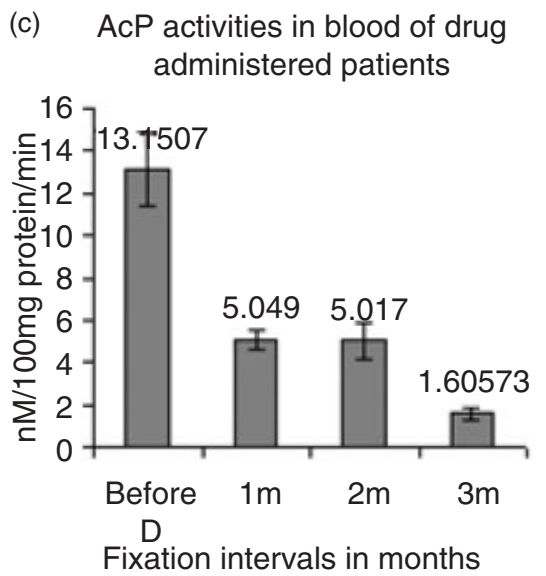

(e) LPO activities in blood of drug administered patients

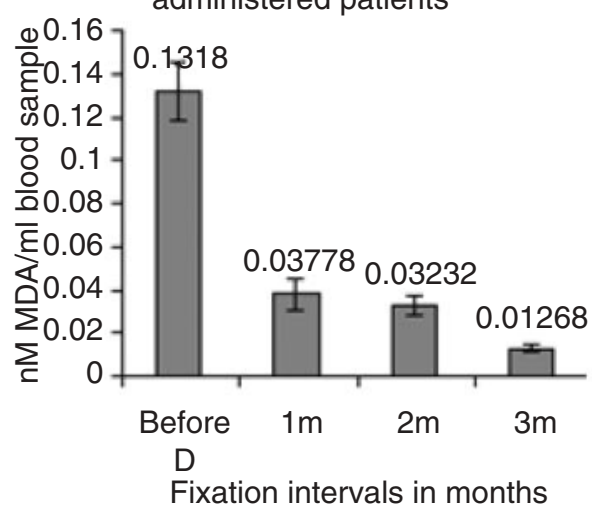

(b) ALT activities in blood of drug administered patients

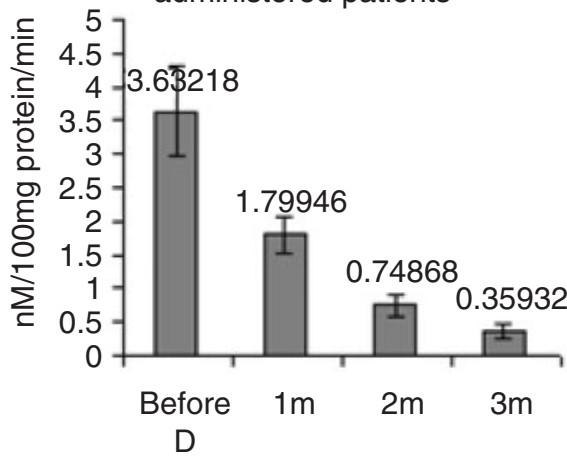

Fixation intervals in months

(d) AlkP activities in blood of drug administered patients

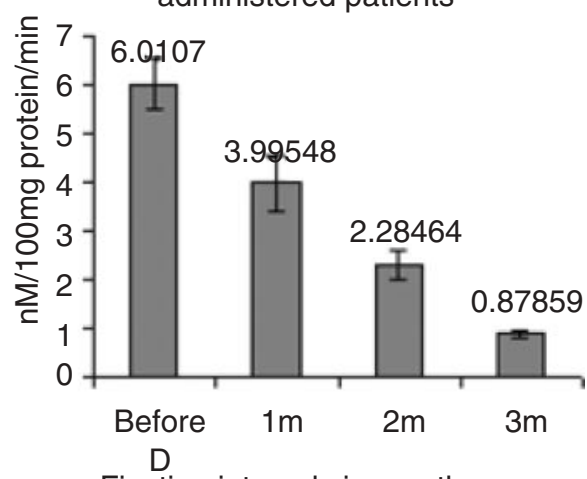

Fixation intervals in months

(f) GSH activities in blood of drug administered patients

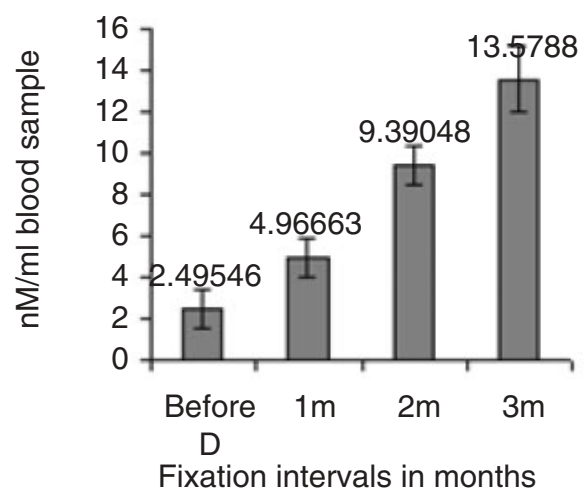

Figure 3. Activities of different biomarkers in blood of verum fed subjects (a) AST (b) ALT (c) AcP (d) AlkP (e) LPO (f) GSH.

aminotransferase) are found in hepatocytes and striated (skeletal and cardiac) muscle cells and increased serum ALT/AST activity has been reported in hepatocellular injury or necrosis of striated muscle $(36,37)$. Determination of ALT activity is a relatively sensitive indicator of hepatic damage and release of ALT from the cytosol can occur secondary to cellular necrosis or as a result of cellular injury with membrane damage and bleb formation (38). Thus, the changes in activity and concentration of marker enzymes like AcP, AlkP, ALT and AST in blood sera could reflect the state of hepatotoxicity (35).
Reduced GSH, a tripeptide containing cysteine, is an important thiol compound present in cells. It plays an crucial role in regulation of cellular proliferation and cellular defense. It has a nucleophilic thiol group and it can modify substances in one of three ways: (i) by chemical reaction with a reactive metabolite to form a conjugate; (ii) by donation of a proton or hydrogen atom to reactive metabolites or free radicals; or (iii) by conjugation catalyzed by a GSH transferase or else other metabolites may chemically oxidize to GSGG from GSH (34). Therefore, exposure of cells to As leads to GSH 


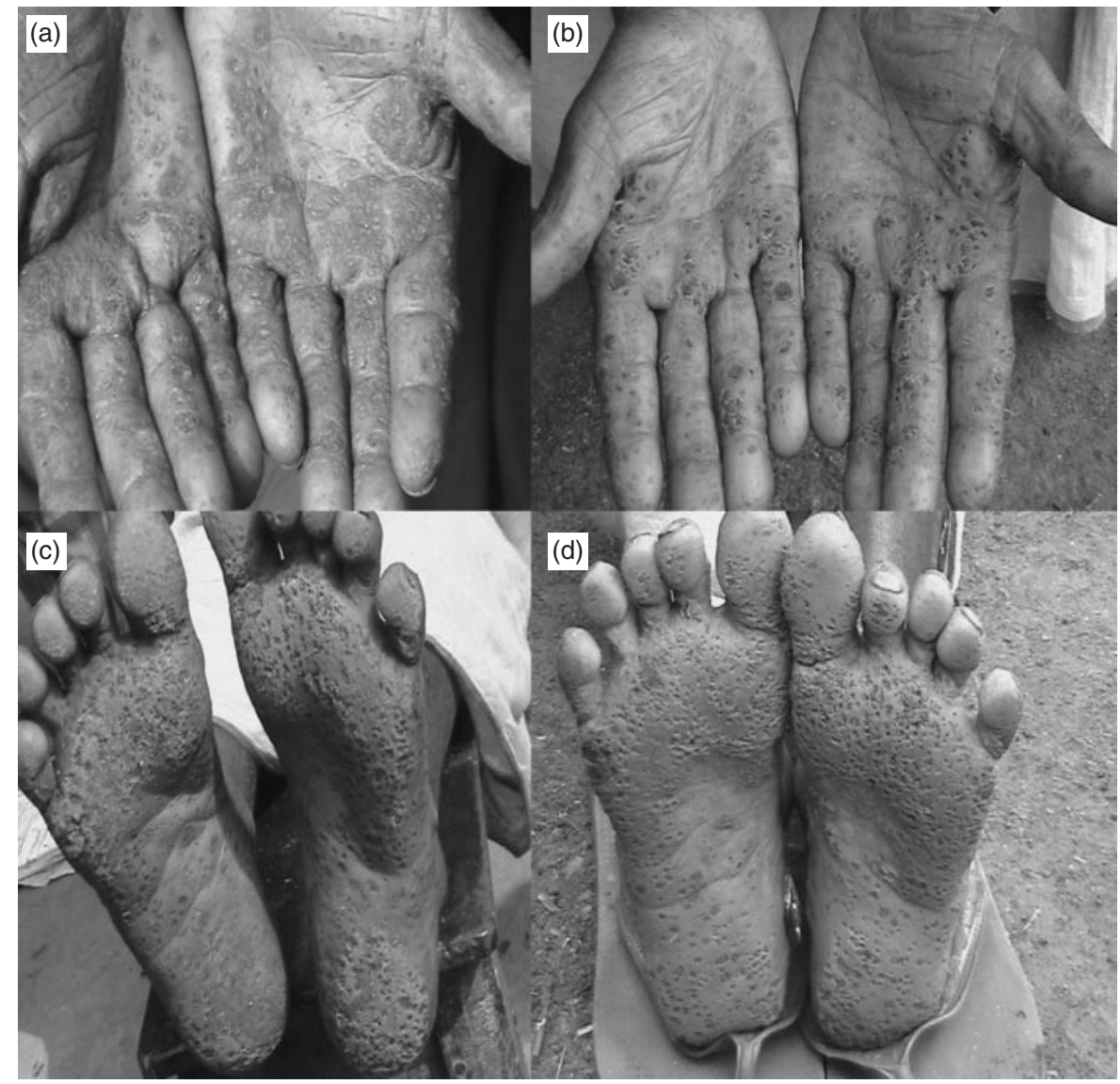

Figure 4. (a-d) Typical skin symptom on palms (upper row) and soles (lower row) of a victim before (left) and 2 months (right) after administration of Arsenicum Album-30.

depletion. Positive alteration in endogenous GSH is encountered in the present investigation after the administration of the homeopathic remedy, which conforms with the activities of the other biomarkers.

Thus, the notable changes observed in activities of these enzymes/biomarkers could be considered as convincing indicators of improvement in hepatic functions, which in turn were amply reflected in increased appetite reported by most of the subjects taking the 'verum' and also as factors influencing the amelioration of other As-induced toxicity.

The present study was essentially a sequel to our earlier randomized placebo-controlled studies (10-16), which had convinced us of the efficacy of the potentized homeopathic remedy, Arsenicum Album-30, to ameliorate As-induced genotoxicity and cytotoxicity in mice (a mammalian model quite close to humans) through the use of several widely accepted cytogenetical and biochemical protocols. Although it would have been preferable to conduct the entire study with a 'double-blind placebo-controlled' protocol to establish the clinical efficacy of this homeopathic remedy on a sounder scientific footing, the positive results obtained in the subjects taking the 'verum' were highly encouraging. They indicated the great potential of the remedy for large-scale use to ameliorate the toxicity induced by chronic intake of groundwater As in millions of poor rural people living in remote places. Even some subjects with bad skin symptoms also started showing signs of improvement. Therefore, this study should provide a stimulus for other researchers to take up further randomized placebo-controlled trials. However, conducting experiments on As victims in As contaminated villages have some inherent limitations since many of the As victims are very sick and suffer from severe depression. To motivate the poor and illiterate villagers to subject themselves to a placebo-controlled study is much more difficult than can be imagined. Furthermore, there is always a risk that a patient's condition will abruptly deteriorate during a placebocontrolled study without the availability of any adequate measures to save his or her life. For this reason, most drug trials made so far by others have only been conducted in either clinics or hospitals. In fact, during our study, a young girl in a critical stage approached us for treatment and was refused in view of her serious condition and was advised for immediate hospitalization; she died only a couple of days later. Had she been included in our study and received a placebo on a randomized basis, a deep sense of sadness and moral responsibility would have plagued the researchers since they would have deprived her of medicine or palliative care during her last few days. Further, monitoring regular uptake of medicine/placebo 
by a large number of subjects in remote As contaminated villages is also an area of concern. Bringing materials (e.g. blood samples) regularly from distant As villages to the laboratory for analysis within a reasonable time frame is another area of difficulty. Despite all these limitations, the initial results indicated in a reasonably convincing way the efficacy of the homeopathic remedy by Arsenicum Album-30 in bringing back the spirit and energy of most As victims, who showed distinct benefits and improvement in their health conditions after administration of the remedy for 3 months.

How the ultralow dose of the drug could bring forth such favorable changes in respect to alleviating As concentration in urine and blood samples and showing positive modulations with respect to different toxicity biomarkers in sera of human volunteers exposed to groundwater As remains unclear. All enzymatic regulations are strictly under genetic control, one possible explanation could be that this ultrahigh diluted drug, on oral administration, must have produced signals through specific receptors to trigger/deactivate some relevant and specific genes $(39,40)$ that could bring forth positive modulations of various parameters in optimizing different functions.

More experiments (preferably double-blind placebocontrolled trials) with larger groups of affected people from adjoining areas is essential before recommending large-scale use of this potentized drug on As affected people. More trials are necessary to examine how long this potency (Arsenicum Album-30) can continue to work effectively (after these initial 3 months) and whether more optimum dose(s)/potency(ies) can yield better and sustainable results. It would also be interesting to know if the duration of intake of the drug on a regular basis can be minimized with the use of a higher potency of the drug (for example, Arsenicum Album-200). At least, poor people inhabiting As-risk areas of the third world countries where provision for safe As-free drinking water has not yet been made or no suitable medical help is available due to the remoteness of the area or any other more efficient drug is made available to them, may be benefited for sometime by taking the drug. But a note of caution: for a sustainable relief from As poisoning, the need for taking 'As-free' drinking water is extremely important and essential, because if As continues to enter, it is simply not possible to maintain outward mobilization of the entire amount for long through the use of any drug alone. Further, the use of some intercurrent 'constitutional' or 'symptomatic' homeopathic remedies may also be necessary depending on the degree of damage already done to different organs through chronic toxicity of this compound, expressing thereby some more specific symptoms. Therefore, a close monitoring of the victims periodically under the supervision of a qualified homeopathic practitioner should be highly encouraged. Further works in these directions are in progress and some other biomarkers are also being considered. We would encourage other groups to conduct similar trials to test the efficacy of the drug and confirm or refute the findings of our pilot study.

\section{Acknowledgments}

A part of this work is financially supported by Boiron, Lyon, France. The authors are grateful to Dr L.N. Mondal, Ex-Vice-Chancellor, BCK Vishwa Vidyalaya, Kalyani, India, Dr Philippe Belon, Director, Boiron Lab, Lyon, France, Dr F.A.C. Weigant, Department of Molecular Biology, University of Utrecht, The Netherlands, for their helpful criticism and kind suggestions for improving the manuscript. Sincere thanks are due to the Directorate of Research, BCKVV, Kalyani, for giving us kind permission to use their AAS for analysis of As content, to Dr Debashis Sarkar, Kalyani and Dr P. Roy-Karmakar, NRS Medical College, Kolkata, for their medical counseling to the patients, to Mr Anup Nandi, licenced paramedic, Chakdaha, for collection of blood from arsenic patients and to Mr P. Pramanik, Joint Secretary, Department of Health and Family Welfare, Government of West Bengal, for issuance of necessary government permission and order for conducting this study in arseniccontaminated villages. The authors are thankful to Prof. D. Chakraborty, School of Environmental Studies, Jadavpur University, Kolkata, for kindly determining the As content of a few samples of urine in his laboratory, that helped us to compare the data with ours. The authors also express their sincere thanks to Mr Biplab Tarafdar for his help in collection of samples and to the large number of arsenic victims who periodically donated samples of urine and blood.

\section{References}

1. Chowdhury UK, Rahman MM, Mondal BK, Paul K, Lodh D, Biswas BK, et al. Groundwater arsenic contamination and human suffering in West Bengal, India and Bangladesh. Environ Sci 2001;8:393-415.

2. WHO. WHO Guidelines for Drinking Water Quality, Vol. 2, 2nd edition. Geneva: WHO, 1996, 940-9.

3. United States Environment Protection Agency, 2001, http://www.epa.gov/ safewater/ars/quickguide.pdf.

4. Guha Mazumder DN, Das Gupta J, Santra A, Pal A, Ghosh A, Sarkar S, et al. Non-cancer effects of chronic arsenicosis with special reference to liver damage. In: Abernathy CO, Calderon RL, Chappell WR (eds). Asenic: Exposure and Health Effects. London: Chapman \& Hall, 1997, 112-23.

5. Ratnaike RN. Acute and chronic arsenic toxicity. Postgrad Med J 2003;79:391-6.

6. Patrick L. Toxic metals and antioxidants: Part II. The role of antioxidants in arsenic and cadmium toxicity. Altern Med Rev 2003;8:106-27.

7. Spallholz JE, Boylan LM, Rhaman MM. Environmental hypothesis: is poor dietary selenium intake an underlying factor for arsenicosis and cancer in Bangladesh and West Bengal, India? Sci Total Environ 2004;323:21-32.

8. Boiron J, Abecassis J, Belon P. A pharmacological study of the retention and mobilization of arsenic, as caused by Hahnemanian potencies of Arsenicum Album. In: Aspects of Research in Homeopathy, Vol. I, 1983, 19-37. Boiron Lab, Lyan, France.

9. Cazin JC, Cazin M, Gaborit JL, Chaoui A, Boiron J, Belon P, et al. A study of the effect of decimal and centesimal dilutions of arsenic on the retention and mobilization of arsenic in the rat. Hum Toxicol 1987;6:315-20.

10. Mitra K, Kundu SN, Khuda-Bukhsh AR. Efficacy of a potentized homoeopathic drug (Arsenicum Album-30) in reducing toxic effects produced by of arsenic trioxide in mice. I. On rate accumulation of arsenic in certain vital organs. Comp Ther Med 1998;6:178-84.

11. Mitra K, Kundu SN, Khuda-Bukhsh AR. Efficacy of a potentized homoeopathic drug (Arsenicum Album-30) in reducing toxic effects produced by of arsenic trioxide in mice. II. On alterations of body weight, tissue weight and total protein. Comp Ther Med 1999;7:24-34. 
12. Datta S, Mallick P, Khuda-Bukhsh AR. Efficacy of a potentized homoeopathic drug (Arsenicum Album-30) in reducing genotoxic effects produced by of arsenic trioxide in mice. I. Comparative studies of pre-, post- and combined pre- and post- oral administration of and comparative efficacy of two microdoses. Comp Ther Med 1998;7:62-75.

13. Datta S, Mallick P, Khuda-Bukhsh AR. Efficacy of a potentized homoeopathic drug (Arsenicum Album-30) in reducing genotoxic effects produced by of arsenic trioxide in mice. II. Comparative efficacy of an antibiotic, Actinomycin D alone and in combination with either of two microdoses of the homeopathic drug, Arsenicum Album. Comp Ther Med 1998; 7:156-63.

14. Kundu SN, Mitra K, Khuda-Bukhsh AR. Efficacy of a potentized homoeopathic drug (Arsenicum Album-30) in reducing cytoxic effects produced by of arsenic trioxide in mice. III. Tissue damage recovery, and enzymatic changes in liver. Comp Ther Med 2000;8:76-81.

15. Kundu SN, Mitra K, Khuda-Bukhsh AR. Efficacy of a potentized homoeopathic drug (Arsenicum Album-30) in reducing cytotoxic effects produced by of arsenic trioxide in mice. IV. On certain pathological conditions, gel electrophoretic protein profiles, DNA and RNA. Comp Ther Med 2000;8:157-65.

16. Mallick P, Chakrabarti Mallick J, Guha B, Khuda-Bukhsh AR. Ameliorating effect of microdoses of a potentized homeopathic drug, Arsenicum Album, on arsenic induced toxicity in mice. BMC Complement Altern Med 2003;3:7.

17. BBC News. Remedy cures arsenic poisoning. 27, October, 2003, http:// www.bbc.co.uk/radio.

18. New Scientist.com news service. Homeopathy reduces arsenic poisoning in mice. 22, October 2003, http://www.newscientist.com/news/.

19. Walter K, Schutt C. Acid and alkaline phosphatases in serum. In: Methods in Enzymatic Analysis, Vol. 2. 1974, 856-60. Academic Press, New York, USA.

20. Bergmeyer HU, Brent E. In: Methods in Enzymatic Analysis, Vol. 2. 1974, 735. Academic Press, New York, USA.

21. Buege JA, Aust SD. Microsomal lipid peroxidation. Methods Enzymol 1984;105:302-10.

22. Ellman GL. Tissue sulfhydril groups. Arch Biochem Biophys 1959;82:70-7.

23. Biggs ML, Kalman DA, Moore LE, Hopen-Rich C, Smith MT, Smith AH. Relationship of urinary arsenic to intake estimates and a biomarker of effect, bladder cell micronuclei. Mutat Res 1997;386:185-95.

24. Vahter M, Concha G, Nermell B, Nilsson R, Dulout F, Natarajan AT. A unique metabolism of inorganic arsenic in native Andean women. Eur J Pharm 1995;293:455-62.

25. Chaudhuri AN, Basu S, Chattopadhyay S, Das Gupta S. Effect of high arsenic content in drinking water on rat brain. Indian J Biochem Biophys 1999;36:51-4.
26. Chowdhury UK, Biswas BK, Chowdhury TR, Samanta G, Mandal BK, Basu GK, et al. Groundwater arsenic contamination in Bangladesh and West Bengal, India. Environ Health Perspect 2000;108: 393-7.

27. Concha G, Vogler G, Lezeano D, Nermell D, Vahter M. Exposure to inorganic arsenic metabolites during early human development. Toxicol Sci 1998;44:185-90.

28. Mandal BK, Ogra Y, Suzuki KT. Speciation of arsenic in human nail and hair from arsenic-affected area by HPLC-inductively coupled argon-plasma mass spectrometry. Toxicol Appl Pharmacol 2003;189: 73-83.

29. Plaa GL. Toxic responses of the liver. In: Klaassen CD, Amdur MO, Doull J (eds). Casarett And Doulls' Toxicology, The Basic Science of Poisons. Macmillan Press: NY, 1986. 236-304.

30. Comporti M. Lipid peroxidation and cellular damage in toxic liver injury. Lab Invest 1985;53:599-623.

31. Banerjee KK, Bishayee A, Chatterjee M. Elevated lipid peroxidation, decreased glutathione levels and changes in glutathione related enzymes in rats treated with human placental extract. Acta Med Okayama 1993;47:223-7.

32. Rossman TG. Mechanism of arsenic carcinogenesis: an integrated approach. Mutat Res 2004;533:37-65.

33. Plaa GL, Amdun AM, Doull J, Klasser CD. Toxic Responses of the Liver, 4th edition. Oxford: Pergamon Press, 1991.

34. Timbrell JA. Principles of Biochemical Toxicology. London: Taylor and Francis, 1991.

35. Vinitha R, Thangaraju M, Sachdanandam P. Effect of administering cyclophosphamide and vitamin $\mathrm{E}$ on the levels of tumor-marker enzymes in rats with experimentally induced fibrosarcoma. Jpn J Med Sci Biol 1995;48:145-56.

36. Bain PJ. Liver. In: Latimer KS, Mahaffey EA, Prasse KW (eds). Duncan and Prasse's Veterinary Medicine: Clinical Pathology, 4th edition. Ames: Iowa State Press, 2003, 193-214.

37. Valentine BA, Blue JT, Shelley SM, Cooper BJ. Increased serum alanine aminotransferase activity associated with muscle necrosis in the dog. $J$ Vet Intern Med 1990;4:140-3.

38. Stockham SL, Scott MA. Fundamentals of Veterinary Clinical Pathology. Ames: Iowa State University Press, 2002, 434-59.

39. Khuda-Bukhsh AR. Potentized homeopathic drugs act through regulation of gene expression: a hypothesis to explain their mechanism and pathways of action in vivo. Com Ther Med 1997;5:43-6.

40. Khuda-Bukhsh AR. Towards understanding molecular mechanisms of action of homeopathic drugs: An overview. Mol Cell Biochem 2003;253: $339-45$. 


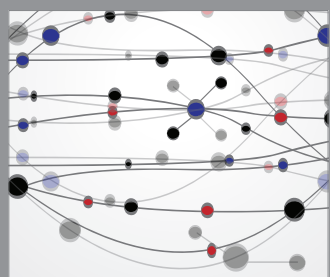

The Scientific World Journal
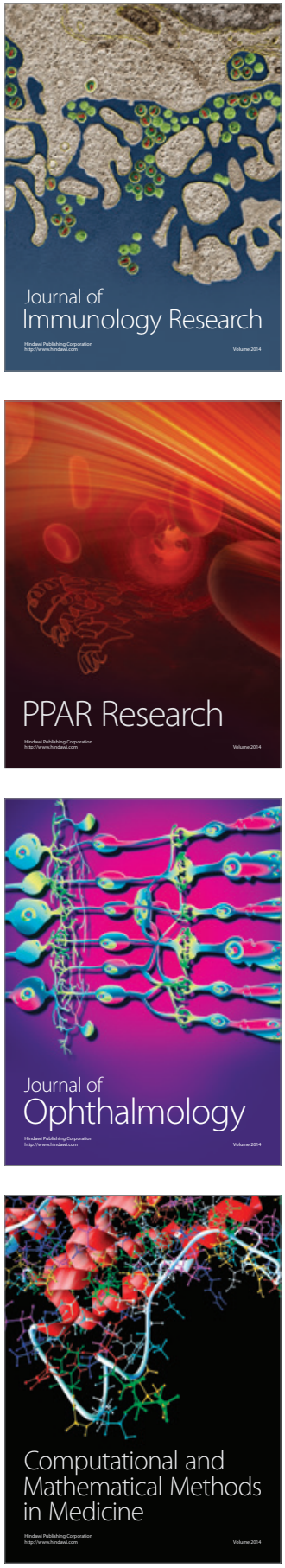

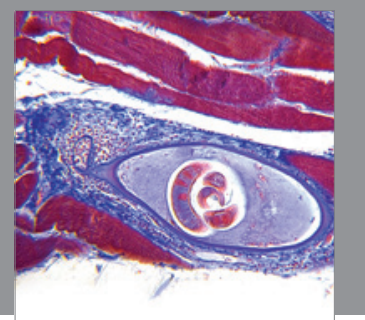

Gastroenterology

Research and Practice
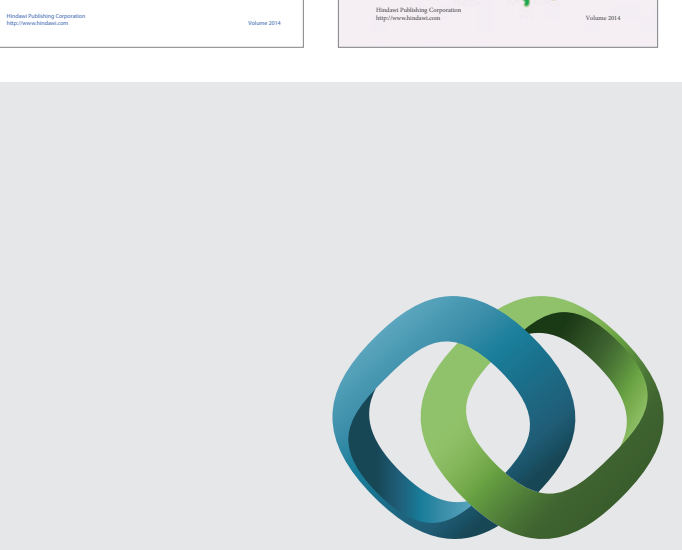

\section{Hindawi}

Submit your manuscripts at

http://www.hindawi.com
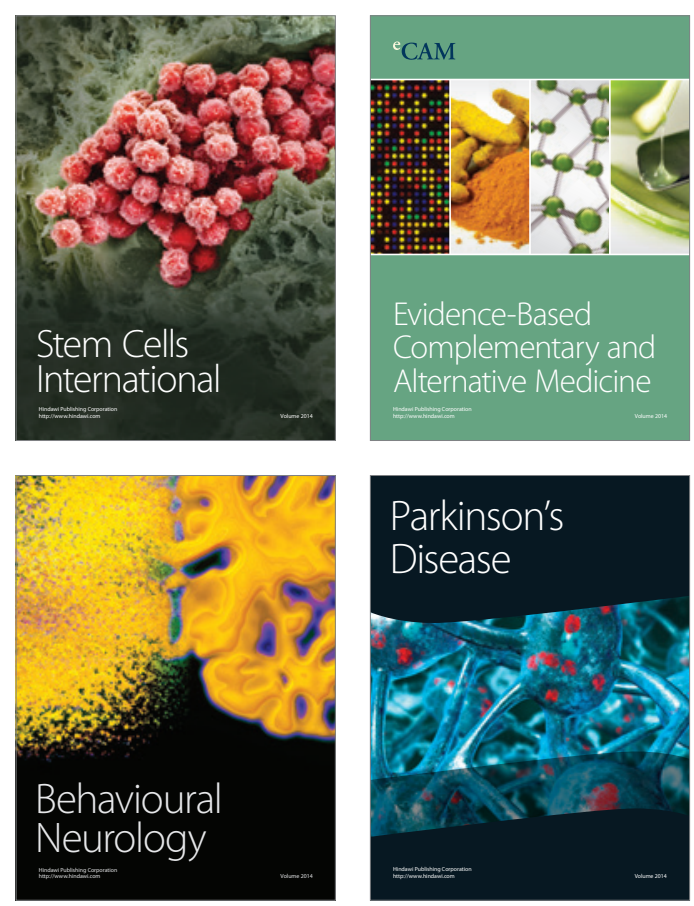

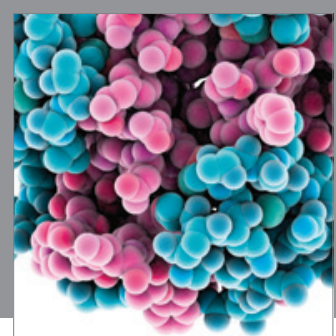

Journal of
Diabetes Research

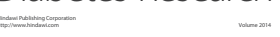

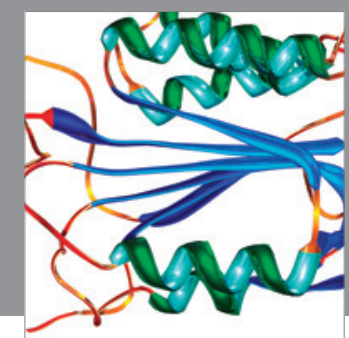

Disease Markers
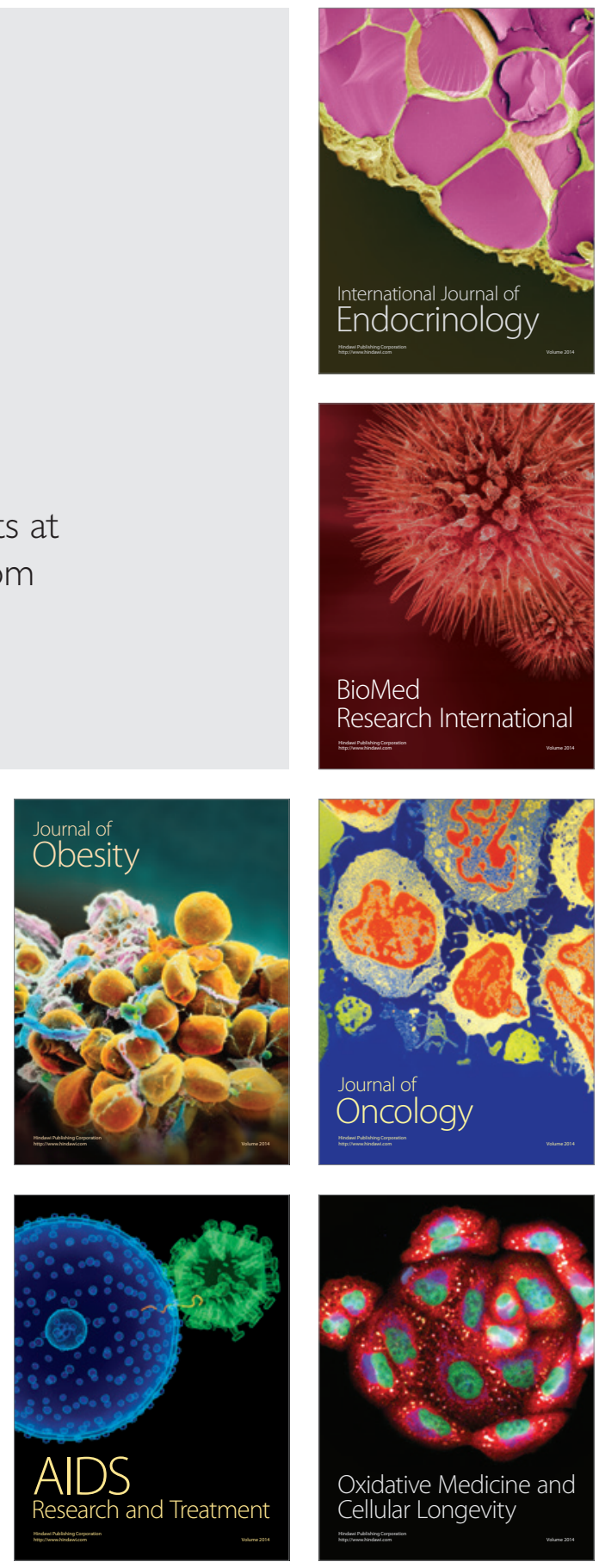